\title{
OCHRONA PRAW DZIECI W PRAWIE POLSKIM I MIĘDZYNARODOWYM W KONTEKŚCIE OCHRONY ICH ZDROWIA
}

\section{Ochrona życia i zdrowia jako prawo fundamentalne. Uwagi ogólne}

W związku z tym, że prawo do ochrony życia, a także prawo do ochrony zdrowia każdego człowieka (bez wyjątku), są ze sobą nierozerwalnie związane (co należy niewątpliwie bardzo wyraźnie podkreślić), należy je rozpatrywać w tej samej płaszczyźnie odniesienia. Ochrona zdrowia służy bowiem ochronie życia ludzkiego w wymiarze doczesnym. Stąd też ochrona zdrowia każdego człowieka, tak jak i prawo do życia, są prawami a zarazem wartościami podstawowymi i fundamentalnymi. Zasygnalizowanie tej, wydawać by się mogło, oczywistej prawdy, ma o tyle istotne znaczenie, że współcześnie, mimo coraz pełniejszej ochrony różnych praw (które takiej ochronie powinny podlegać), mamy do czynienia ze zjawiskiem różnych form relatywizacji prawa do ochrony życia (problem kary śmierci, eutanazji, aborcji itd.) i prawa do ochrony zdrowia (związane np. $\mathrm{z}$ traktowaniem prawa do ochrony zdrowia, także wtedy, kiedy zapisane ono zostało w Konstytucji, jako normy programowej). Niestety, także godność człowieka ujmuje się niejednokrotnie instrumentalnie, mimo, że jest ona źródłem wszelkich praw i wolności. To życie ludzkie, a przez to $\mathrm{w}$ dalszej perspektywie prawo do ochrony zdrowia, stanowią uosobienie i swoistą kwintesencję godności człowieka. Transcendentny wymiar bytowania człowieka byłby niezrozumiały bez widzenia go w kontekście godności człowieka, prawa do życia oraz prawa do ochrony zdrowia, które najpełniej uosabiają godność człowieka, a także jego transwp.pl.

Prof. dr hab., Uniwersytet Marii Curie-Skłodowskiej w Lublinie; e-mail: zdybm@ 
cendentność. Uwolnienie człowieka od tych wartości może uczynić realizację innych praw i wolności niemożliwymi, także dlatego, że ich utrata w wymiarze doczesnym, oznacza niemożność korzystania z innych praw. Jako prawo fundamentalne uosabiające istotę godności człowieka jest prawem ponadpaństwowym i przysługuje człowiekowi tylko dlatego, że jest człowiekiem, a nie dlatego, że prawodawca zapisał je w konkretnym akcie normatywnym.

Mając na uwadze powyższe, przypomnieć należy dwa ważne z punktu widzenia ochrony tychże praw wyroki Trybunału Konstytucyjnego (TK). W wyroku TK z dnia 15 listopada 2000 r., uznając powyższe prawa za podstawowe i fundamentalne, przyjął, że:

Ustawodawca [tego rodzaju praw - M.Z.] z reguły nie może ich nie tylko kwestionować, ale i ograniczać. Nie są one w zasadniczej swojej treści uzależnione od woli prawodawcy, a tym bardziej od organów stosujących prawo, bez względu na to, czy będą to organy administracji publicznej, czy sądy. Stąd określa się je mianem praw przyrodzonych. Z nimi wiąże się niewątpliwie konstytucyjna teza o nienaruszalności godności człowieka. Takie rozumowanie nawiązuje do preambuły i art. 1 Deklaracji Praw Człowieka i Obywatela, z których wynika zasada, że z racji urodzenia się człowiekiem - a nie na podstawie innych aktów i czynności prawnych - człowiek jest podmiotem wszystkich praw wynikających z jego człowieczeństwa. W tym znaczeniu godność człowieka nie jest uzależniona od woli ustrojodawcy (prawodawcy) ${ }^{1}$.

W innym wyroku TK z dnia 7 stycznia 2004 r. w sprawie K 14/03 z 2004 r. ${ }^{2}$, powołując się na pogląd prezentowany przez J. Bocia uznał, że:

To, co nie budzi wątpliwości dotyczy ochrony życia rozumianej jako ochrona biologicznej egzystencji człowieka. Poza tym mamy tu do czynienia z prawem wobec państwa pierwotnym, co oznacza, iż państwo takiego prawa człowiekowi przyznać nie może, a jedynie może podkreślić jego istnienie i znaczenie, poddając to prawo szczególnej ochronie. Na organach państwa spoczywa obowiązek stanowienia takiego prawa, by chroniło ono życie, $i$ to życie każdego człowieka niezależnie od tego, w jakiej sytuacji znajduje się․

1 Wyrok Trybunału Konstytucyjnego z dnia 15 listopada 2000 r., P 12/99, OTK ZU nr 7/2000, poz. 260.

2 Wyrok Trybunału Konstytucyjnego z dnia 7 stycznia 2004 r., K 14/03, OTK 1/1A/2004. Sprawozdawcą w tej sprawie był autor niniejszego tekstu.

3 Tamże; zob. też J. Boć (red.), Konstytucje Rzeczypospolitej oraz komentarz do Konstytucji RP z 1997 roku, Wrocław 1998, s. 78. 
Z aksjologicznego punktu widzenia bardzo ważne znaczenie dla określenia podmiotowości prawnej człowieka i istoty fundamentalnych praw człowieka, w tym zwłaszcza dziecka, miały poglądy papieża Jana Pawła II przedstawione m.in. w jego opracowaniach książkowych, encyklikach, wystąpieniach i przesłaniach ${ }^{4}$. Na uwagę zasługują tu także poglądy prezentowane przez M.A. Krąpca, zwłaszcza monografie: Ja - cztowiek, Cztowiek jako osoba ${ }^{5}$. Do poglądów tych nawiązuje szereg przedstawicieli doktryny, nie tylko społecznej nauki Kościoła i personalizmu prawniczego. Stosowną literaturę prawniczą i filozoficzną $\mathrm{w}$ tym zakresie przywołuję $\mathrm{w}$ innych moich publikacjach dotyczących ochrony zdrowia ${ }^{6}$.

Oczywiście mając na uwadze okoliczność, że w świetle art. 68 ust. 1 Konstytucji RP każdy ma prawo do ochrony zdrowia, należałoby bezwarunkowo przyjąć, że prawo takie posiadają także dzieci. Co więcej, wedle art. 68 ust. 3 Konstytucji RP państwo ma obowiązek zapewnienia szczególnej opieki zdrowotnej m.in. dzieciom i kobietom ciężarnym. Takie wskazanie w Konstytucji rodzi ściśle określone konsekwencje prawne. Jest to uzasadnione, jak i konieczne. Ta szczególna ochrona jest związana z faktem, że dziecko, bez względu na to czy znajduje się w łonie matki, czy też rozwija się samodzielnie, wymaga szczególnej opieki zarówno ze strony matki (rodziców), jak i państwa w całym procesie rozwoju od poczęcia aż do uzyskania dojrzałości, pozwalającej na samodzielne kształtowanie

4 Zob. Jan Paweł II, Miłość i odpowiedzialność, Lublin 1960; tenże, Osoba i czyn, Kraków 1969; tenże, Znak, któremu sprzeciwiać się będa, Paryż 1980; tenże, Przekroczyć próg nadziei, Lublin 1994; encykliki, w tym przede wszystkim: tenże, Encyklika "Veritatis splendor" o niektórych podstawowych problemach nauczania moralnego Kościoła, Kraków 1993; tenże, Encyklika „Evangelium vitae” o wartości i nienaruszalności życia ludzkiego, Kraków 1995; wystąpienia, homilie i przesłania, w tym: tenże, Nowa ewangelizacja a godność człowieka cierpiącego. Orędzie Jana Pawła II na IX Światowy Dzień Chorego A.D. 2001, Poznań 2001; tenże, Przestanie do członków Papieskiej Akademii "Pro Vita” (19.II.2005 r.), "W obronie życia i zdrowia każdej osoby ludzkiej", [w:] K. Gryz (oprac.), Godność: antologia tekstów, Kraków 2011, s. 27-28.

5 Zob. M.A. Krąpiec, Ja - człowiek, Lublin 1974; tenże, Człowiek jako osoba, Lublin 2011; tenże, Człowiek i prawo naturalne, Lublin 2009.

6 Zob. M. Zdyb, Aksjologiczne podstawy ochrony zdrowia, [w:] J. Pacian (red.), Prawna ochrona zdrowia pacjenta, Warszawa 2017, s. 11-33; tenże, Wspótczesne aksjologiczne dylematy realizacji prawa do ochrony zdrowia przez władze publiczne i odpowiedzialności z tym związanej, [w:] M. Zdyb, E. Kruk, A. Wołoszyn-Cichocka (red.), Odpowiedzialność w ochronie zdrowia, Warszawa 2018; tenże, Systemowe obowiązki państwa w zakresie poszukiwania optymalnego modelu odpowiedzialności związanej z ochrona zdrowia. Zagadnienia podstawowe, [w:] M. Zdyb, E. Kruk, A. Wołoszyn-Cichocka (red.), Odpowiedzialność w ochronie zdrowia, Warszawa 2018, s. 19-31. 
swojej pozycji. Z tej też racji oczekiwać należy, że w tym okresie będzie ono zabezpieczane $\mathrm{w}$ różnych sferach, $\mathrm{w}$ tym także $\mathrm{w}$ zakresie ochrony zdrowia. $W$ takim stanie rzeczy zasadne jest udzielenie odpowiedzi na pytanie: kto jest dzieckiem?

\section{Aksjologiczne podstawy określenia pojęcia dziecka}

W różnego rodzaju sporach politycznych, prawnych i doktrynalnych, pojawiają się rozbieżności w zakresie dotyczącym określenia, kto jest dzieckiem w rozumieniu prawa. Mając na uwadze różnorodne podejścia dotyczące określenia tego, w którym momencie dziecko staje się dzieckiem, oznacza nieuzasadnioną relatywizację problemu. Tworzy niebezpieczeństwo dowolności $\mathrm{w}$ tym zakresie. Trzeba bowiem pamiętać o tym, że stanowisko oponentów w stosunku do tezy, że dziecko staje się dzieckiem z momentem poczęcia, określa w tym zakresie, nie zawsze jednakowe cezury czasowe, co mnożyć może kolejne wątpliwości. Należy także pamiętać, że, przyjmując jako fundamentalną zasadę prawo do życia, wszelkie wątpliwości, które mają oponenci w zakresie określenia momentu, w którym płodowi ludzkiemu przypisać można byłoby przymiot godności ludzkiej w tym zakresie, należałoby tłumaczyć na korzyść zasady. Niezrozumiałe staje się w ostatnich czasach podnoszenie do rangi zasady tez odbiegających od niej.

Sama Konstytucja wprawdzie nie definiuje pojęcia dziecka jednakże daje podstawy do wypracowania jednolitego stanowiska. W tym kontekście należałoby brać pod uwagę nie tylko art. 68 ust. 1 Konstytucji RP, ale i także inne przepisy Konstytucji, w tym przede wszystkim art. 38 (prawo do życia), art. 30 (godność człowieka), art. 2 (wskazujący na to, że Rzeczpospolita Polska jest demokratycznym państwem prawa urzeczywistniającym zasady sprawiedliwości społecznej) czy art. 72 (w artykule tym zdanie pierwsze, w którym stwierdza się, że „Rzeczpospolita Polska zapewnia ochronę praw dziecka") itd. Wprawdzie w Konstytucji wprost nie określa się pojęcia dziecka, ani żadnych momentów dotyczących górnej i dolnej granicy w tym zakresie, ale z całokształtu rozwiązań konstytucyjnych oraz aksjologicznych podstaw ładu prawnego i wartości, na których opiera się porządek prawny, jednoznacznie wynika, że dzieckiem jest istota ludzka od momentu poczęcia. Całkowicie podzielam stanowisko zajęte przez wybitnych przedstawicieli doktryny (w tym konsekwentnie przez A. Zolla), że 
godność ludzką i prawo do życia, a przez to także prawo do ochrony zdrowia, posiada każdy człowiek, a więc istota ludzka posiadająca genom ludzki. Nawet Europejski Trybunał Sprawiedliwości, który ma niejednokrotnie skłonności do relatywizowania podstawowych wartości, przyjął, że „ludzki embrion jest obdarzony godnością od momentu połączenia komórki męskiej i żeńskiej, a istota obdarzona godnością wymaga ochrony prawnej".

Niewątpliwie bardzo ważne znaczenie, w kontekście ochrony życia i zdrowia dzieci, ma ustawa z dnia 6 stycznia 2000 r. o Rzeczniku Praw Dziecka7, która stanowi swoiste wypełnienie i identyfikację wartości wynikających z Konstytucji (art. 72 ust. 1 i 4) i będącą także swoistą aksjomatyzacją treści wynikających z innych rozwiązań ustawowych. Ustawa ta, znajdując konkretne umocowanie w Konstytucji, w art. 2 formułuje ustawowe pojęcie dziecka, wedle której „dzieckiem jest każda istota ludzka od momentu poczęcia do osiągnięcia pełnoletności". Biorąc pod uwagę okoliczność dotyczącą legitymizowania tejże ustawy i jej przepisów oraz systemowe podejście do prawa uznać należy, że jest to pojęcie rodzące wszelkie skutki prawne związane z jego normatywnym charakterem. Niedopuszczalne byłoby więc formułowanie w aktach normatywnych rozwiązań prawnych, które pozostawałyby z nią w sprzeczności. Ustawodawca przyjął w definiowaniu tegoż pojęcia formułę nie zakładającą odstępstw od zasady, która nie miałaby legitymacji w obowiązującej Konstytucji. Takie podejście wydaje się w pełni uprawnione. Zdarzało się bowiem, że w drodze ustawy przewidywano możliwość niedopuszczalnego i nie mającego umocowania w Konstytucji wprowadzania odstępstw zawężających zakres ochrony konstytucyjnej. Taka sytuacja miała miejsce w 1996 r., kiedy to ustawa z dnia 30 sierpnia 1996 r. o zmianie ustawy o planowaniu rodziny, ochronie płodu ludzkiego i warunkach dopuszczalności przerywania ciąży oraz zmianie niektórych innych ustaw ${ }^{8}$ dokonała istotnej zmiany ustawy o planowaniu rodziny, ochronie płodu ludzkiego i warunkach dopuszczalności przerywania ciąży z dnia 7 stycznia 1993 r., niekorzystnych z punktu widzenia ochrony życia i zdrowia dziecka, w tym też dziecka poczętego'.

7 Ustawa z dnia 6 stycznia 2000 r. o Rzeczniku Praw Dziecka, tekst jednolity: Dz. U. z 2017 r. poz. 922 z późn. zm.

8 Ustawa z dnia 30 sierpnia 1996 r. o zmianie ustawy o planowaniu rodziny, ochronie płodu ludzkiego i warunkach dopuszczalności przerywania ciąży oraz zmianie niektórych innych ustaw, Dz. U. z 1996 r. Nr 139, poz. 646.

9 Trybunał Konstytucyjny w wyroku tym orzekł m.in., że: „art. 1 pkt 2 ustawy z dnia 30 sierpnia 1996 r. o zmianie ustawy o planowaniu rodziny, ochronie płodu ludzkiego i wa- 
Istotne jest to, że przy wydawaniu tegoż orzeczenia ${ }^{10}$ Trybunał powołał się na wzorce konstytucyjne ustawy konstytucyjnej z dnia 17 października 1992 r. o wzajemnych stosunkach między władzą ustawodawczą i wykonawczą Rzeczypospolitej Polskiej oraz o samorządzie terytorialnym ${ }^{11}$ oraz art. 79 ust. 1 przepisów konstytucyjnych pozostawionych przez ww. ustawę konstytucyjną w mocy. Gdyby orzekał na podstawie aktualnie obowiązującej Konstytucji RP miałby niewątpliwie szersze możliwości uzasadnienia swojego stanowiska (niż odniesienie do zasady demokratycznego państwa prawnego i prawa do ochrony macierzyństwa).

Ważne znaczenie w kontekście analizowanego orzeczenia Trybunału miało zakwestionowanie art. 1 ust. 2 badanej ustawy, który przyjął: „Prawo do życia podlega ochronie, w tym również w fazie prenatalnej w gra-

runkach dopuszczalności przerywania ciąży oraz zmianie niektórych innych ustaw (Dz. U. Nr 139, poz. 646), w zakresie w jakim uzależnia ochronę życia w fazie prenatalnej od decyzji ustawodawcy zwykłego, jest niezgodny z art. 1 oraz art. 79 ust. 1 przepisów konstytucyjnych pozostawionych w mocy na podstawie art. 77 Ustawy Konstytucyjnej z dnia 17 października 1992 r. o wzajemnych stosunkach między władzą ustawodawczą i wykonawczą Rzeczypospolitej Polskiej oraz o samorządzie terytorialnym (Dz. U. Nr 84, poz. 426; zm.: z 1995 r. Nr 38, poz. 148; Nr 150, poz. 729; z 1996 r. Nr 106, poz. 488) przez to, że narusza konstytucyjne gwarancje ochrony życia ludzkiego w każdej fazie jego rozwoju; [...]".

Podobnie orzekł niekonstytucyjność, powołując się na te same wzorce konstytucyjne: treści art. 1 pkt 5 kwestionowanej ustawy z dnia 30 sierpnia 1996 r. uznając, że „legalizuje przerwanie ciąży bez dostatecznego usprawiedliwienia koniecznością ochrony innej wartości, prawa lub wolności konstytucyjnej oraz posługuje się nieokreślonymi kryteriami tej legalizacji, naruszając w ten sposób gwarancje konstytucyjne dla życia ludzkiego"; art. 3 pkt 4 ww. ustawy, ponieważ uznał, że „ograniczył prawną ochronę zdrowia dziecka poczętego do tego stopnia, że pozostałe środki prawne nie spełniają wymogów dostatecznej ochrony tej wartości konstytucyjnej"; art. 2 pkt 2 tejże ustawy przez to, że "pozbawiając dziecko możliwości dochodzenia swych roszczeń majątkowych wobec matki, ograniczył jego prawa w sposób sprzeczny z zasadą demokratycznego państwa prawnego i z zasadą równości”; art. 3 pkt 1 ww. ustawy przez to, że „naruszył gwarancje konstytucyjne odnoszące się do ochrony zdrowia dziecka poczętego i jego niezakłóconego rozwoju”. Argumentacja przyjęta $\mathrm{w}$ uzasadnieniu tychże rozstrzygnięć służy niewątpliwie pełniejszej ochronie praw, w tym prawa do życia i prawa do ochrony zdrowia, zwłaszcza dziecka poczętego (jeszcze nienarodzonego).

10 Zob. wyrok Trybunału Konstytucyjnego z dnia 28 maja 1997 r., K 26/96, OTK ZU nr 2/1997, poz. 19.

11 Ustawa konstytucyjna z dnia 17 października 1992 r. o wzajemnych stosunkach między władzą ustawodawczą i wykonawczą Rzeczypospolitej Polskiej oraz o samorządzie terytorialnym, Dz. U. z 1992 r. Nr 84, poz. 426 ze zm.: z 1995 r. Nr 38, poz. 148; Nr 150, poz. 729; z 1996 r. Nr 106, poz. 488. 
nicach określonych w ustawie". Przenosi to możliwość dość swobodnej regulacji problemu dziecka w ogóle, w tym dziecka poczętego, zwłaszcza w realiach ówczesnej ustawy konstytucyjnej. Takie rozwiązanie eliminowało kluczową wydaje się zasadę ładu prawnego w Rzeczypospolitej, wedle której „każda istota ludzka ma od chwili poczęcia przyrodzone prawo do życia i ochrony zdrowia", którą formułowała wyraźnie ustawa z 1993 r. o planowaniu rodziny, ochronie płodu ludzkiego i warunkach dopuszczalności przerywania ciąży.

Trybunał Konstytucyjny w uzasadnieniu swojego orzeczenia przyją:

Jeżeli bowiem życie człowieka, w tym życie dziecka poczętego, stanowi wartość konstytucyjną, to ustawa zwykła nie może prowadzić do swoistej cenzury i zawieszenia obowiązywania norm konstytucyjnych. Zakaz naruszania życia ludzkiego, w tym życia dziecka poczętego wynika z norm o charakterze konstytucyjnym. W takiej sytuacji ustawodawca zwykły nie może więc być uprawniony do decydowania o warunkach obowiązywania takiego zakazu, czyniąc tym samym normy konstytucyjne normami o charakterze warunkowym. Nie może w szczególności uzależniać go od regulacji zawartych w ustawach zwykłych. Stąd też sprzeczne z normami konstytucyjnymi jest stanowienie przez ustawodawcę zwykłego wszelkich takich regulacji, które prowadziłoby do jedynie warunkowego obowiązywania gwarancji konstytucyjnych ${ }^{12}$.

Dzisiaj bardzo poważnym problemem jest nadmierna pozytywizacja prawa, nadmierna wiara $\mathrm{w}$ nieomylność prawodawcy (za którym stać ma wola suwerena) i negacja prawa naturalnego jako fundamentu ładu prawnego i swoistego korelatu wartości fundamentalnych. Zapomina się, że są prawa, których państwo nam nie nadaje, takie jak prawo do życia, prawo do ochrony zdrowia itd. Z reguły deklarują je konstytucje, przez co następuje ich identyfikacja na gruncie prawa pozytywnego. Trzeba jednak pamiętać, że w tym zakresie większość polityczna nie może tych praw w szerszym lub węższym zakresie - unicestwiać. Dlatego tak bardzo ważne jest dziś określenie np. gdzie jest początek, a gdzie koniec życia? Gdzie jest początek ludzkiego bytowania i życia dziecka? Dzisiaj nawet w naukach przyrodniczych nie przedstawia się przekonywujących dowodów na to, że to jest jakiś inny moment niż moment poczęcia.

Nikt dziś nie zaprzecza temu, że w momencie zapłodnienia komórki jajowej mamy do czynienia z zupełnie nowym organizmem, nowym kodem genetycznym, różniącym się od kodu genetycznego matki. To jest nowy

12 Wyrok Trybunału Konstytucyjnego z dnia 28 maja 1997 r., K 26/96. 
człowiek. Również na płaszczyźnie prawnej to jest odrębna istota. Na przykład polska ustawa o rzeczniku praw dziecka bardzo wyraźnie nakłada na rzecznika obowiązek występowania w obronie dziecka od momentu poczęcia. W Europejskiej Konwencji Bioetycznej mowa jest o istocie ludzkiej od samego początku życia. Europejski Trybunał Sprawiedliwości jasno stwierdził, że człowiekowi od momentu poczęcia przysługuje atrybut godności, dlatego w żadnym razie nie może być traktowany przedmiotowo ${ }^{13}$.

Moment poczęcia jest niewątpliwie tym, w którym rodzi się podmiotowość prawna dziecka, przynajmniej w zakresie prawa do życia i prawa do ochrony zdrowia. Stąd w wielu aktach prawa międzynarodowego (o czym dalej) uznaje się godność człowieka, którą posiada on od momentu poczęcia i która jest nienaruszalna. Żaden ustawodawca tej godności nie przyznaje, a więc nie może także jej pozbawić. Aborcja (bez względu na to jak doszło do ciąży, bez względu na stan zdrowia dziecka) kłóci się i pozostaje w sprzeczności z prawem pierwotnym w stosunku do prawa pozytywnego. Zabiera człowiekowi to, co jest wyznacznikiem jego ziemskiego bytowania. Poważnym problemem w tym zakresie jest istnienie sytuacji nadzwyczajnych i stanów wyższej konieczności, zwłaszcza wtedy, gdy każde rozwiązanie rodzić może konieczność rozstrzygnięć ostatecznych i niejednokrotnie dokonywania bardzo trudnych wyborów. Pamiętać należy także o tym, że taki stan rzeczy nakłada poważne obowiązki na państwo, np. w przypadku urodzenia się dziecka z różnorodnymi formami niepełnosprawności fizycznej i umysłowej. Niestety w tym zakresie rozwiązania dotyczące funkcjonowania takich dzieci w społeczeństwie, jak i problem pomocy finansowej i pozafinansowej, leczenia niepełnosprawności nie został w stopniu zadawalającym rozwiązany w prawie polskim.

Reasumując można stwierdzić, że:

Granice - jak to określa A. Zoll - ochrony życia ludzkiego nie mogą być regulowane przez ustawodawcę. To jest wartość przyrodzona. Ja mam prawo do ochrony życia w momencie, kiedy stałem się człowiekiem, czyli od momentu zapłodnienia komórki jajowej jestem podmiotem tego podstawowego prawa, a w stosunku do państwa mam roszczenie o jego ochronę $e^{14}$.

13 A. Zoll, Aborcja jest bezprawna, https://info.wiara.pl/doc/1008673.Aborcja-jest-bezprawna/2 [dostęp: 27.08.2018 r.].

14 A. Zoll, Bezsporne jest, że dziecko poczęte jest człowiekiem. Teraz trzeba wyciagnać z tego odpowiednie konsekwencje, https://wpolityce.pl/polityka/120478-prof-andrzej-zoll [dostęp: 27.08.2018 r.]. 
Przyjmując, że podmiotem prawa dziecka do ochrony życia i zdrowia jest istota ludzka od momentu poczęcia do osiągnięcia pełnoletności zasadne jest krótkie ustosunkowanie się i wskazanie górnej granicy dziecięcości. W świetle przyjętej przez Zgromadzenie Ogólne Narodów Zjednoczonych dnia 20 listopada 1989 r. Konwencji o prawach dziecka ${ }^{15}$, pełnoletniość dziecko zyskuje z chwilą ukończenia 18 lat, chyba że przepisy prawne przewidują możliwość wcześniejszego jej uzyskania. W prawie polskim kluczowe znaczenie $\mathrm{w}$ tej materii ma ustawa $\mathrm{z}$ dnia 23 kwietnia 1964 r. - Kodeks cywilny ${ }^{16}$, który w art. $10 \S 1$, podobnie jak ww. konwencji, przyjmuje, że co do zasady w Polsce pełnoletniość uzyskuje się po ukończeniu 18 lat. $W$ art. $10 \S 2$ przewiduje się możliwość uzyskania jej z ważnych powodów za zezwoleniem sądu opiekuńczego, który może zezwolić „na zawarcie małżeństwa kobiecie, która ukończyła lat szesnaście, a z okoliczności wynika, że zawarcie małżeństwa będzie zgodne z dobrem założonej rodziny". Przez ten fakt uzyskuje status osoby pełnoletniej, którego nie traci $w$ razie ustania małżeństwa. Ponadto przepisy prawa mogą $\mathrm{w}$ przewidzianych $\mathrm{w}$ prawie sytuacjach traktować tak jak dzieci osoby, które przekroczyły 18 lat - jednakże tylko w odniesieniu do niektórych, prawem przewidzianych, sytuacji.

\section{Konstytucyjna ochrona zdrowia dzieci}

Nie ulega wątpliwości, że w sprawach dotyczących spraw fundamentalnych (tak jak i w innych krajach) bardzo ważne znaczenie ma Konstytucja RP, ponieważ jest nosicielem wartości, które dość często mają głębszy, ponadpozytywnoprawny wymiar. Zawiera identyfikację tych praw, które $\mathrm{w}$ aksjologicznej perspektywie stanowią uosobienie praw przyrodzonych, niezależnych od woli prawodawcy. Stanowią one przez to punkt odniesienia dla prawodawców i organów stosujących prawo. W odniesieniu do dzieci w całej rozciągłości odnoszą się te prawa sformułowane w Konstytucji RP, które odnoszą się w ogóle do człowieka. Na uwadze tutaj należy

15 Konwencja o prawach dziecka, przyjęta przez Zgromadzenie Ogólne Narodów Zjednoczonych dnia 20 listopada 1989 r., Dz. U. z 1991 r. Nr 120, poz. 526.

16 Ustawa z dnia 23 kwietnia 1964 r. - Kodeks cywilny, tekst jednolity: Dz. U. z 2019 r. poz. 1145. 
mieć przede wszystkim: art. 30 Konstytucji podkreślający znaczenie godności człowieka jako źródła wszelkich praw i wolności; art. 38, w którym sformułowano prawo do życia; art. 68 dotyczący prawa do ochrony zdrowia, a także zasadę demokratycznego państwa prawnego urzeczywistniającego zasady sprawiedliwości społecznej.

Wskazać należałoby także te prawa konstytucyjne, które tylko pośrednio związane są ze statusem dziecka np.: art. 18, w którym wyraźnie podkreśla się, co bardzo ważne, że „rodzina, macierzyństwo i rodzicielstwo znajdują się pod ochroną i opieką Rzeczypospolitej Polskiej”; art. 48: „Rodzice mają prawo do wychowania dzieci zgodnie z własnymi przekonaniami. Wychowanie to powinno uwzględniać stopień dojrzałości dziecka, a także wolność jego sumienia i wyznania oraz jego przekonania”; art. 53 ust. 3: „Rodzice mają prawo do zapewnienia dzieciom wychowania i nauczania moralnego i religijnego zgodnie ze swoimi przekonaniami”; art. 71 ust. 1: „Państwo w swojej polityce społecznej i gospodarczej uwzględnia dobro rodziny. Rodziny znajdujące się w trudnej sytuacji materialnej i społecznej, zwłaszcza wielodzietne i niepełne, mają prawo do szczególnej pomocy ze strony władz publicznych”; art. 71 ust. 2: „Matka przed i po urodzeniu dziecka ma prawo do szczególnej pomocy władz publicznych, której zakres określa ustawa" itd. Przepisy te $\mathrm{w}$ dużej części zwracają uwagę na znaczenie rodziny jako źródła swoistego ładu w okresie wzrastania i dojrzewania dzieci.

Ochrona praw dziecka - słusznie zauważa M. Derkacz - jest powiązana w sposób naturalny z prawami adresowanymi do rodziny, ponieważ dziecko jest naturalnym elementem rodziny, która równocześnie stanowi niezbędne środowisko dla jego prawidłowego rozwoju. $\mathrm{W}$ ramach ochrony rodziny państwo szczególne miejsce zarezerwowało dla dziecka ${ }^{17}$.

17 M. Derkacz, Konstytucyjne prawo dziecka do szczególnej opieki zdrowotnej, Warszawa 2016, s. 31. Słusznie zauważa on w tejże publikacji, że: "Zgodnie z dyspozycją zawartą w art. 18 Konstytucji rodzina, macierzyństwo i rodzicielstwo są pod państwową ochroną. Przepis ten podkreśla znaczenie rodziny jako spełniającej funkcje podstawowej grupy społecznej. Nie można zapominać, że dziecko jest zawsze immanentnym członkiem rodziny, bez niego nie byłoby ani macierzyństwa, ani rodzicielstwa. Pierwszoplanowa rola w odniesieniu do państwowej struktury wewnętrznej przypada właśnie rodzinie i jest to jedno z najważniejszych przesłań dla ustawodawcy zwykłego, jednocześnie stanowiąc pewien punkt odniesienia do wyznaczania celów państwowej polityki społecznej. Tak doniosła pozycja rodziny, macierzyństwa i rodzicielstwa oznacza także, że pozycja dziecka jako integralnego elementu tych pojęć prawnych powinna mieć należytą ochronę władz publicznych działających na rzecz i w imieniu państwa", tamże, s. 117. 
Konstytucja podkreśla (art. 71 ust. 1 i 2) i deklaruje dobro rodziny jako wartość konstytucyjną, co wiąże się z koniecznością tworzenia takiego systemu prawnego, który sprzyjał będzie jej kondycji ujmowanej w różnych płaszczyznach, zwłaszcza w przypadku trudnej sytuacji materialnej. To może się wiązać (a przynajmniej powinno) z należytą realizacją przez państwo prawa matki (zarówno przed urodzeniem dziecka jak i po jego urodzeniu) do szczególnej pomocy ze strony władz publicznych. Dotyczy to także pomocy rodzinom wielodzietnym i niepełnym znajdującym się $\mathrm{w}$ trudnej sytuacji materialnej.

W perspektywie niniejszych wywodów należy pamiętać o treści kilku ważnych, wynikających z Konstytucji RP, problemach, na które zwracał uwagę Trybunał Konstytucyjny (zarówno na bazie aktualnie obowiązującej Konstytucji, jak i ustawy konstytucyjnej z dnia 17 października 1992 r. o wzajemnych stosunkach między władzą ustawodawczą i wykonawczą Rzeczypospolitej Polskiej oraz o samorządzie terytorialnym), część doktryny, orzecznictwo sądowe itd.

Po pierwsze, że zdrowie dzieci po urodzeniu, ale także i dziecka poczętego, nie jest należycie chronione, a niektóre przepisy ustaw naruszały w tym zakresie (czy też nadal naruszają) aksjologiczne podstawy ładu prawnego ukształtowane przez stosowne przepisy konstytucyjne. Przykładowo - mając to na uwadze - Trybunał Konstytucyjny w przywoływanym wielokrotnie orzeczeniu z dnia 28 maja 1997 r. (w sprawie o sygn. K 26/96) zakwestionował m.in. art. 1 pkt 2 , art. 3 pkt 1 i art. 3 pkt 4 ustawy z dnia 30 sierpnia 1996 r. o zmianie ustawy o planowaniu rodziny, ochronie płodu ludzkiego i warunkach dopuszczalności przerywania ciąży [chodzi tu o ustawę z dnia 7 stycznia 1993 r. - uwaga M.Z.] oraz zmianie niektórych innych ustaw ${ }^{18}$, ze względu na to, że zostały nadmiernie zawężająco uregulowane (nawet w stosunku do poprzednich przepisów nowelizowanej ustawy), ponieważ normy te nie wspominały - jak stwierdził - „o ochronie prawnej zdrowia dziecka, w tym dziecka poczętego", a poza tym, nie zawierały „deklaracji o przyrodzonym charakterze prawa do życia". Ponadto inaczej określały „okres, w którym prawo do życia podlega ochronie prawnej".

Po drugie, ustalono, że „zdrowie człowieka, w tym dziecka poczętego, ma bez wątpienia walor wartości konstytucyjnie chronionej. Wszelkie

18 Ustawa z dnia 30 sierpnia 1996 r. o zmianie ustawy o planowaniu rodziny, ochronie płodu ludzkiego i warunkach dopuszczalności przerywania ciąży oraz zmianie niektórych innych ustaw, Dz. U. z 1996 r. Nr 139, poz. 646 z późn. zm. 
zachowania nakierowane na naruszenie zdrowia człowieka muszą być uznane, $\mathrm{z}$ tego punktu widzenia, za zachowania naruszające dobro prawne”. Także „rezygnacja z dostatecznych środków ochrony dobra stanowiącego wartość konstytucyjną musi być uznana za naruszającą gwarancje konstytucyjne takiego dobra".

Po trzecie, zwrócić należy uwagę na szczególne znaczenie dla ochrony zdrowia dziecka art. 68 ust. 3 Konstytucji RP, który mając na uwadze prawo do ochrony zdrowia w ogóle oraz problem finansowania procedur medycznych ze środków publicznych, zwrócił uwagę na zadania państwa w tej materii podkreślając obowiązek władz publicznych zapewnienia „szczególnej opieki zdrowotnej dzieciom, kobietom ciężarnym, osobom niepełnosprawnym". Nakłada to na ustawodawcę obowiązek wprowadzenia stosownych rozwiązań prawnych, które czyniłyby zadość konstytucyjnym wymaganiom. Niewątpliwie istnieje dziś potrzeba, np. w stosunku do dzieci niepełnosprawnych (także innych osób niepełnosprawnych), wprowadzenia roztropnych w tej materii rozwiązań prawnych. Milczenie ustawodawcy w tym zakresie prowadzi do szeregu ujemnych skutków - rodzących ujemne konsekwencje - podobnie zresztą jak i wadliwość różnych istniejących rozwiązań prawnych. Zdrowia dzieci dotyczy także art. 68 ust. 4 i 5, w których zwraca się uwagę na obowiązki państwa w zakresie - sprzyjającego ochronie zdrowia - rozwoju kultury fizycznej dzieci i młodzieży, a także na obowiązki w zakresie ochrony środowiska i zwalczania chorób epidemiologicznych.

Po czwarte, ważne znaczenie dla przyszłości dzieci mają te regulacje prawne, które dotyczą ochrony rodziny i macierzyństwa (słusznie przyjął TK w sprawie o sygn. K 26/96, że nikt inny poza matką nie jest w stanie w fazie prenatalnej podtrzymać życia dziecka poczętego i zapewnić mu możliwość optymalnego rozwoju) oraz znaczenia wychowania dzieci w rodzinie.

Reasumując stwierdzić należy, że Konstytucja RP jest (powinna być) gwarantem optymalnej ochrony zdrowia dziecka. Jednak duże znaczenie ma także to, czy ustawodawcy prawidłowo odczytują jej treść.

\section{Ochrona praw dziecka w sferze ochrony zdrowia w kontekście prawa międzynarodowego}

W następstwie aktywności różnego rodzaju organizacji i stowarzyszeń działających na przełomie XIX i XX w., zwiększyło się zaintereso- 
wanie ochroną praw dziecka, $w$ tym ochroną zdrowia. Znalazło to wyraz w przyjętej przez Zgromadzenie Ogólne Ligi Narodów w dniu 26 września 1924 r. Deklaracji Praw Dziecka ${ }^{19}$. W późniejszym okresie niemal we wszystkich najważniejszych aktach (konwencjach prawa międzynarodowego) prawa dziecka i ochrona ich zdrowia znalazły stosowne odzwierciedlenie, w tym w uchwalonych 16 grudnia 1966 r. przez Zgromadzenie Ogólne ONZ: Pakcie Praw Gospodarczych, Socjalnych i Kulturalnych ${ }^{20}$ oraz Międzynarodowym Pakcie Praw Obywatelskich i Politycznych ${ }^{21}$, które weszły w życie 3 stycznia 1976 r., a także w szeregu innych aktach prawa międzynarodowego.

Niewątpliwie w zakresie ochrony praw dziecka kluczowe znaczenie ma aktualnie Konwencja o prawach dziecka przyjęta przez Zgromadzenie Ogólne Narodów Zjednoczonych w dniu 20 listopada 1989 r., którą Polska ratyfikowała ${ }^{22}$. Na znaczenie tejże konwencji i innych aktów prawa międzynarodowego zwraca się baczną uwagę w literaturze prawniczej ${ }^{23}$. Istotne jest to, że już w preambule konwencja odwołuje się do wartości wynikających z innych aktów prawa międzynarodowego, a mających na celu poszanowanie praw dziecka. Stwierdza się, że tę konwencję uchwala się

mając na uwadze, że potrzeba otoczenia dziecka szczególną troską została wyrażona w Genewskiej Deklaracji Praw Dziecka z 1924 r. oraz Deklaracji Praw Dziecka przyjętej przez Zgromadzenie Ogólne 20 listopada 1959 r. i uznanej w Ogólnej Deklaracji Praw Człowieka, w Międzynarodowym Pakcie Praw Obywatelskich i Politycznych (w szczególności w artykułach 23 i 24), w Międzynarodowym Pakcie Praw Gospodarczych, Społecznych i Kultural-

19 Zob. J. Kondratiewa-Bryzik, Początek prawnej ochrony życia ludzkiego w świetle standardów międzynarodowych, Warszawa 2009, s. 85-86.

20 Zob. Z. Kędzia, Międzynarodowy Pakt Praw Gospodarczych, Socjalnych i Kulturalnych. Komentarz, Warszawa 2018.

${ }^{21}$ Zob. A. Gliszczyńska, Międzynarodowy Pakt Praw Obywatelskich i Politycznych. Komentarz, Warszawa 2018.

22 Oświadczenie Rządowe z dnia 30 września 1991 r. w sprawie ratyfikacji przez Rzeczpospolitą Polską Konwencji o prawach dziecka, przyjętej przez Zgromadzenie Ogólne Narodów Zjednoczonych dnia 20 listopada 1989 r., Dz. U. z 1991 r. Nr 120, poz. 527.

23 Zob. J. Krukowski, Kościót i państwo: podstawy relacji prawnych, Lublin 1993, s. 187; J. Kondratiewa-Bryzik, Początek prawnej..., s. 85-86; J. Bińczycka (red.), Prawa dziecka - deklaracje i rzeczywistość. Materiaty z Konferencji Rembertów 19-21 czerwca 1992, Kraków 1993; M. Andrzejewski, Konwencja o Prawach Dziecka - geneza i znaczenie , „Problemy Opiekuńczo-Wychowawcze” 2000, nr 5, s. 3-7; H. Czerwińska, Prawo dziecka do godnego życia, „Remedium" 2003, nr 2, s. 1-3. 
nych (w szczególności w artykule 10), jak również w statutach i stosownych dokumentach wyspecjalizowanych agencji i międzynarodowych organizacji zajmujących się zapewnieniem dobrobytu dzieciom,

ponieważ „dziecko powinno być w pełni przygotowane do życia w społeczeństwie jako indywidualnie ukształtowana jednostka, wychowana w duchu ideałów zawartych w Karcie Narodów Zjednoczonych, a w szczególności w duchu pokoju, godności, tolerancji, wolności, równości i solidarności".

W rozumieniu art. 1 konwencji dzieckiem jest każda istota ludzka w wieku do 18 lat. Dopuszcza jednak - jako wyjątek od zasady - możliwość uzyskania pełnoletniości w okresie wcześniejszym. Z konwencji wynika niewątpliwie przesłanie, że dzieci są istotami ludzkimi jeszcze słabymi, budującymi swoją tożsamość, indywidualność, a także duchowość, w czym pomagać im powinni dorośli, ze szczególnym uwzględnieniem rodziców i rodziny. Ta słabość w okresie wzrastania, przekształcić ma się w siłę społeczeństw. Dlatego należy im się specjalna troska we wszystkich płaszczyznach ich ludzkiego bytowania. To tworzy obowiązek kierowania się zawsze dobrem dziecka, bez jakiejkolwiek formy ich różnicowania. Konwencja o prawach dziecka, którą ratyfikowały 192 kraje, nazywana jest często międzynarodową konstytucją praw dzieci. Zawiera szereg fundamentalnych praw, których omawianie w niniejszym artykule jestem zmuszony pominąć. Zwrócić jednak należy uwagę na art. 24 ust. 2, w którym konwencja zobowiązuje do podejmowania wszelkich działań zmierzających w kierunku:

a) zmniejszenia śmiertelności wśród noworodków i dzieci; b) zapewnienia udzielania koniecznej pomocy oraz opieki zdrowotnej wszystkim dzieciom, ze szczególnym uwzględnieniem rozwoju podstawowej opieki zdrowotnej; c) zwalczania chorób i niedożywienia, w tym - w ramach podstawowej opieki zdrowotnej - przez wykorzystanie między innymi łatwo dostępnych technik oraz przez dostarczanie odpowiednich pożywnych produktów żywnościowych i wody pitnej, z uwzględnieniem niebezpieczeństwa oraz ryzyka zanieczyszczenia środowiska naturalnego; d) zapewnienia matkom właściwej opieki zdrowotnej w okresie przed i po urodzeniu dziecka; e) zapewnienia, aby wszystkie grupy społeczne, w szczególności rodzice oraz dzieci, były informowane i posiadały dostęp do oświaty oraz otrzymywały wsparcie w korzystaniu z podstawowej wiedzy w zakresie zdrowia dziecka i karmienia, korzyści z karmienia piersią, higieny i warunków zdrowotnych otoczenia, a także zapobiegania wypadkom [...]. 
Obowiązki takie - co istotne - nałożone zostały na państwa sygnatariuszy. Wiążą się one także z koniecznością zapewnienia dzieciom niepełnosprawnym możliwości stosownej ochrony.

Na szczególne podkreślenie zasługuje (niemająca charakteru normatywnego) Deklaracja Praw Dziecka uchwalona przez Zgromadzenie Ogólne ONZ w dniu 20 listopada 1959 r. ${ }^{24} \mathrm{~W}$ deklaracji tej, składającej się z preambuły i 10 zasad, zaapelowano o uwzględnienie tych zasad w prawie poszczególnych państw oraz w działaniach rodziców, podkreślając, że „ludzkość powinna dać dziecku to, co ma najlepszego" oraz zapewnić mu „szczęśliwe dzieciństwo i korzystanie, zarówno w jego interesie, jak i w interesie społeczeństwa, z [określonych w niej - M.Z.] praw i swobód [...]"25.

\section{Problem ochrony zdrowia dzieci i realizacji prawa do ochrony zdrowia w kontekście ustawodawstwa polskiego}

Niewątpliwie problem realizacji prawa do ochrony zdrowia na poziomie Konstytucji RP i prawa międzynarodowego prowadzi do wskazania aksjologicznych podstaw obowiązującego w tej materii prawa. Mówiąc $\mathrm{w}$ tej materii o systemie ochrony prawa do zdrowia, trzeba wskazać na całokształt ustaw, które zabezpieczają to prawo. Szerzej problem ten omówiony został w opracowaniu pt. Wspótczesne aksjologiczne dylematy realizacji prawa do ochrony zdrowia przez władze publiczne i odpowiedzialności z tym zwia$z_{a n e j}{ }^{26}$. Podstawowe zagadnienia rozwinięte zostały także w innej publikacji pt. Systemowe obowiazki Państwa w zakresie poszukiwania optymalnego modelu odpowiedzialności związanej z ochrona zdrowia. Zagadnienia podstawowe ${ }^{27}$.

24 Deklaracja Praw Dziecka uchwalona przez Zgromadzenie Ogólne ONZ w dniu 20 listopada 1959 roku, https://www.ms.gov.pl/Data/Files/_public/ppwd/akty_prawne/onz/deklaracja_praw_dziecka.pdf [dostęp: 26.08.2018 r.].

25 Tę problematykę poruszał m.in. A. Klafkowski, zob. tenże, Prawo międzynarodowe publiczne, Warszawa 1979, s. 283.

26 Zob. M. Zdyb, Wspótczesne aksjologiczne dylematy realizacji prawa do ochrony zdrowia przez wtadze publiczne i odpowiedzialności z tym związanej, [w:] M. Zdyb, E. Kruk, A. Wołoszyn-Cichocka (red.), Odpowiedzialność w ochronie zdrowia, Warszawa 2018, s. 5-18.

27 Zob. M. Zdyb, Systemowe obowiązi państwa w zakresie poszukiwania optymalnego modelu odpowiedzialności zwiąanej z ochrona zdrowia. Zagadnienia podstawowe, [w:] M. Zdyb, E. Kruk, A. Wołoszyn-Cichocka (red.), Odpowiedzialność w ochronie zdrowia, Warszawa 2018, s. 19-32. 
Nie ulega wątpliwości, że bardzo ważne znaczenie w tej materii mają ustawy, które można by uznać jako fundamentalne o bardzo szerokim zakresie, dotykające zarówno dzieci jak i dorosłych. Wymienić tu można takie jak: ustawa z dnia 15 kwietnia 2011 r. o działalności leczniczeje28; ustawa z dnia 6 listopada 2008 r. o prawach pacjenta i Rzeczniku Praw Pacjenta ${ }^{29}$; ustawa z dnia 15 lipca 2011 r. o zawodach pielęgniarki i położnej ${ }^{30}$; ustawa z dnia 5 grudnia 1996 r. o zawodzie lekarza i lekarza dentysty $^{31}$; ustawa z dnia 2 grudnia 2009 r. o izbach lekarskich ${ }^{32}$; ustawa z dnia 27 sierpnia 2004 r. o świadczeniach opieki zdrowotnej finansowanych ze środków publicznych ${ }^{33}$; ustawa z dnia 7 stycznia 1993 r. o planowaniu rodziny, ochronie płodu ludzkiego i warunkach dopuszczalności przerywania ciąży ${ }^{34}$ itd.

Dużą doniosłość z punktu widzenia zdrowia dzieci (tak jak i dorosłych) mają ustawy ukierunkowane na różne aspekty ochrony zdrowia, takie jak: ustawa z dnia 19 sierpnia 1994 r. o ochronie zdrowia psychicznego ${ }^{35}$; ustawa z dnia 28 lipca 2005 r. o lecznictwie uzdrowiskowym, uzdrowiskach i obszarach ochrony uzdrowiskowej oraz gminach uzdrowiskowych ${ }^{36}$; ustawa z dnia 5 grudnia 2008 r. o zapobieganiu oraz zwalczaniu zakażeń i chorób zakaźnych u ludzi ${ }^{37}$; ustawa z dnia 1 lipca 2009 r.

28 Ustawa z dnia 15 kwietnia 2011 r. o działalności leczniczej, tekst jednolity: Dz. U. z 2018 r. poz. 2190 z późn. zm.

29 Ustawa z dnia 6 listopada 2008 r. o prawach pacjenta i Rzeczniku Praw Pacjenta, tekst jednolity: Dz. U. z 2019 r. poz. 1127 z późn. zm.

30 Ustawa z dnia 15 lipca 2011 r. o zawodach pielęgniarki i położnej, tekst jednolity: Dz. U. z 2019 r. poz. 576 z późn. zm.

31 Ustawa z dnia 5 grudnia 1996 r. o zawodzie lekarza i lekarza dentysty, tekst jednolity: Dz. U. z 2019 r. poz. 537 z późn. zm.

32 Ustawa z dnia 2 grudnia 2009 r. o izbach lekarskich, tekst jednolity: Dz. U. z 2019 r. poz. 965 .

33 Ustawa z dnia 27 sierpnia 2004 r. o świadczeniach opieki zdrowotnej finansowanych ze środków publicznych, tekst jednolity: Dz. U. z 2019 r. poz. 1373 z późn. zm.

34 Ustawa z dnia 7 stycznia 1993 r. o planowaniu rodziny, ochronie płodu ludzkiego i warunkach dopuszczalności przerywania ciąży, Dz. U. z 1993 r. Nr 17, poz. 78 z późn. zm.

35 Ustawa z dnia 19 sierpnia 1994 r. o ochronie zdrowia psychicznego, tekst jednolity: Dz. U. z 2018 r. poz. 1878 z późn. zm.

36 Ustawa z dnia 28 lipca 2005 r. o lecznictwie uzdrowiskowym, uzdrowiskach i obszarach ochrony uzdrowiskowej oraz gminach uzdrowiskowych, tekst jednolity: Dz. U. z 2017 r. poz. 1056 z późn. zm.

37 Ustawa z dnia 5 grudnia 2008 r. o zapobieganiu oraz zwalczaniu zakażeń i chorób zakaźnych u ludzi, tekst jednolity: Dz. U. z 2019 r. poz. 1239 z późn. zm. 
o pobieraniu, przechowywaniu i przeszczepianiu komórek tkanek i narządów ${ }^{38}$; ustawa z dnia 6 listopada 2008 r. o akredytacji w ochronie zdrowia $^{39}$; ustawa z dnia 27 lipca 2001 r. o diagnostyce laboratoryjnej ${ }^{40}$; ustawa z dnia 19 sierpnia 1994 r. o ochronie zdrowia psychicznego ${ }^{41}$.

Ważną kategorię ustaw tworzą te, które dotyczą dopuszczenia i wytwarzania oraz finansowania środków medycznych służących ochronie zdrowia. Wymienić tu należy przede wszystkim takie akty normatywne jak: ustawa z dnia 6 września 2001 r. - Prawo farmaceutyczne ${ }^{42}$; ustawa z dnia 2 grudnia 2009 r. o izbach lekarskich ${ }^{43}$; ustawa z dnia 6 września 2001 r. - Przepisy wprowadzające ustawę - Prawo farmaceutyczne, ustawę o wyrobach medycznych oraz ustawę o Urzędzie Rejestracji Produktów Leczniczych, Wyrobów Medycznych i Produktów Biobójczych ${ }^{44}$; ustawa z dnia 12 maja 2011 r. o refundacji leków, środków spożywczych specjalnego przeznaczenia żywieniowego oraz wyrobów medycznych ${ }^{45}$; ustawa z dnia 18 marca 2011 r. o Urzędzie Rejestracji Produktów Leczniczych, Wyrobów Medycznych i Produktów Biobójczych ${ }^{46}$; ustawa z dnia 20 maja 2010 r. o wyrobach medycznych ${ }^{47}$.

38 Ustawa z dnia 1 lipca 2009 r. o pobieraniu, przechowywaniu i przeszczepianiu komórek tkanek i narządów, tekst jednolity: Dz. U. z 2019 r. poz. 1405.

39 Ustawa z dnia 6 listopada 2008 r. o akredytacji w ochronie zdrowia, tekst jednolity: Dz. U. z 2016 r. poz. 2135.

40 Ustawa z dnia 27 lipca 2001 r. o diagnostyce laboratoryjnej, tekst jednolity: Dz. U. z 2019 r. poz. 849.

41 Ustawa z dnia 19 sierpnia 1994 r. o ochronie zdrowia psychicznego, tekst jednolity: Dz. U. z 2018 r. poz. 1878 z późn. zm.

42 Ustawa z dnia 6 września 2001 r. - Prawo farmaceutyczne, tekst jednolity: Dz. U. z 2019 r. poz. 499 z późn. zm.

43 Ustawa z dnia 2 grudnia 2009 r. o izbach lekarskich, tekst jednolity: Dz. U. z 2019 r. poz. 965.

44 Ustawa z dnia 6 września 2001 r. - Przepisy wprowadzające ustawę - Prawo farmaceutyczne, ustawę o wyrobach medycznych oraz ustawę o Urzędzie Rejestracji Produktów Leczniczych, Wyrobów Medycznych i Produktów Biobójczych, tekst jednolity: Dz. U. z 2001 r. Nr 126, poz. 1382 z późn. zm.

45 Ustawa z dnia 12 maja 2011 r. o refundacji leków, środków spożywczych specjalnego przeznaczenia żywieniowego oraz wyrobów medycznych, tekst jednolity: Dz. U. z 2019 r. poz. 784 z późn. zm.

46 Ustawa z dnia 18 marca 2011 r. o Urzędzie Rejestracji Produktów Leczniczych, Wyrobów Medycznych i Produktów Biobójczych, tekst jednolity: Dz. U. z 2019 r. poz. 662.

47 Ustawa z dnia 20 maja 2010 r. o wyrobach medycznych, tekst jednolity: Dz. U. z 2019 r. poz. 175 z późn. zm. 
Niewątpliwie stan prawa polskiego w zakresie dotyczącym praw dziecka w zakresie ochrony zdrowia jest niedoskonały. Na kilka problemów należałoby zwrócić uwagę.

Po pierwsze, dla optymalnego funkcjonowania prawa w tym zakresie konieczna jest systemowa jego spójność i konieczność eliminowana różnego rodzaju dysfunkcjonalności w sferze ustrojowej, aksjologicznej, dotyczącej odpowiedzialności, w sferze ochrony zdrowia, relacji pomiędzy podstawowymi aktami prawnymi itd. Mając na uwadze taki stan rzeczy Trybunał Konstytucyjny w wyroku z dnia 7 stycznia 2004 r. (sygn. akt K $14 / 03)^{48}$ orzekł niekonstytucyjność prawie całej ustawy z dnia 23 stycznia 2003 r. o powszechnym ubezpieczeniu w Narodowym Funduszu Zdrowia ${ }^{49}$, w tym przepisów prawnych dotyczących zasad działania oraz organizacji Narodowego Funduszu Zdrowia, regulacji w zakresie zabezpieczenia potrzeb zdrowotnych i organizacji udzielania świadczeń zdrowotnych (rozdziały, finansów i gospodarki finansowej, nadzoru i kontroli wykonywania zadań itd.).

Wiele wątpliwości budzi jakość obowiązującego prawa i związanych z tym problemów takich jak: wyzwolenie prawa od wartości, ograniczenie poczucia pewności prawa, nadmiar prawa i jego inflacja, niespójność prawa medycznego, chaos pojęciowy, oderwanie prawa od realiów, niezupełność rozwiązań prawnych (np. w zakresie praw pacjenta), nadmiar regulacji o charakterze deklaratoryjnym, niezrozumiałość prawa, brak precyzji w zakresie określenia podstawowych pojęć itd..$^{50}$

Po drugie, większość regulacji prawnych z zakresu ochrony zdrowia, które kształtują system ochrony zdrowia w Polsce ${ }^{51}$, co do zasady, dotyczy

48 Wyrok Trybunału Konstytucyjnego z dnia 7 stycznia 2004 r., K 14/03, OTK ZU $1 / 1 \mathrm{~A} / 2004$.

49 Ustawa z dnia 23 stycznia 2003 r. o powszechnym ubezpieczeniu w Narodowym Funduszu Zdrowia, Dz. U. z 2003 r. Nr 45, poz. 391 z późn. zm.

50 Szerzej na ten temat zob. M. Zdyb, Dylematy ładu prawnego w kontekście inflacji i niektórych innych niedoskonatości prawa administracyjnego, [w:] J. Jagielski, M. Wierzbowski (red.), Prawo administracyjne dziś i jutro, Warszawa 2018, s. 39-50.

51 Szerzej na ten temat zob. M. Dercz, H. Izdebski, T. Rek, Dziecko - pacjent $i$ świadczeniobiorca. Poradnik prawny, Warszawa 2015; M. Dercz, H. Izdebski., T. Rek, Prawo publiczne ochrony zdrowia, Warszawa 2015; M. Dercz, T. Rek, Ustawa o działalności leczniczej. Komentarz, Warszawa 2014; M. Dercz, Konstytucyjne podstawy praw dziecka do ochrony zdrowia i zadania władz publicznych w zakresie zapewnienia ich dostępności, [w:] M. Dercz, H. Izdebski, T. Rek, Dziecko - pacjent i świadczeniobiorca. Poradnik prawny, Warszawa 2015, s. 51 i nast.; K. Prokop, Prawo do ochrony zdrowia w świetle art. 68 Konstytucji RP, [w:] T. Mróz (red.), 
ochrony zdrowia wszystkich obywateli, co wydaje się zrozumiałe pod warunkiem, że uwzględniać się będzie specyfikę związaną z zagrożeniami i ochroną zdrowia dzieci. Niestety w większości przypadków, np. w zakresie refundacji leków, prawa farmaceutycznego, profilaktyki medycznej (problem lekarzy w szkołach), zdrowia psychicznego itd., uregulowane zostały w sposób niezadowalający.

Po trzecie, zasadne jest pełniejsze uregulowanie praw dziecka w zakresie dotyczącym praw pacjenta. Nie ulega wątpliwości, że cenna była inicjatywa dotycząca uregulowania tychże praw w odrębnej ustawie, czego konsekwencją była ustawa z 2008 r. o prawach pacjenta i Rzeczniku Praw Pacjenta. Ustawa ta dokonała identyfikacji podstawowych praw pacjenta wymieniając m.in.: prawo pacjenta do świadczeń zdrowotnych, prawo pacjenta do informacji, prawo do zgłaszania działań niepożądanych produktów leczniczych, prawo pacjenta do tajemnicy informacji z nim związanych, prawo do poszanowania intymności i godności pacjenta, prawo pacjenta do dokumentacji medycznej, prawo pacjenta do zgłoszenia sprzeciwu wobec opinii albo orzeczenia lekarza, prawo pacjenta do poszanowania życia prywatnego i rodzinnego, prawo pacjenta do opieki duszpasterskiej, prawo pacjenta do przechowywania rzeczy wartościowych w depozycie itd. Nie ulega wątpliwości, że wykaz ten budzi - podobnie jak i w innych krajach - poważny niedosyt. Stąd też podjęto na poziomie ponadnarodowym próbę określenia najważniejszych praw, $\mathrm{w}$ tym też praw dziecka przebywającego $\mathrm{w}$ szpitali.

Po czwarte, niepokojące wydają się dziś dla ochrony życia i zdrowia dzieci i młodzieży zjawiska związane ze zwalczaniem narkomanii oraz nowego problemu tzw. „dopalaczy”. O ile zjawisko narkomanii zastało w pewnym sensie zdefiniowane (chociaż sama ustawa o zwalczaniu narkomanii jest wysoce niedoskonała), to wobec problemu "dopalaczy” prawodawca jest bezsilny, ze względu na nieograniczone możliwości zmiany ich struktury chemicznej. Utrudnia to możliwości leczenia i zapobiegania niepożądanym skutkom dla zdrowia i życia. Problem "dopalaczy” pojawił się w latach 80., gdy zwiększyła się skuteczność państw w zwalczaniu narkomanii. To zaowocowało procederem wytwarzania chemicznych środków zawierających substancje psychoaktywne. W związku z tym, że

Uwarunkowania prawne, ekonomiczne i socjologiczne funkcjonowania wybranych systemów ochrony zdrowia, Białystok 2011, s. 39; M. Gawrońska, Prawo do ochrony zdrowia na gruncie Konstytucji Rzeczypospolitej Polskiej, „Przegląd Prawa Publicznego” 2014, nr 2, s. 14. 
ustawodawca pozostawał z reguły $\mathrm{w}$ tyle za pomysłami producentów dopalaczy, nie zdała egzaminu zasada dopisywania do ustawy kolejnych rodzajów "dopalaczy", a nawet wprowadzane zakazy wytwarzania i dystrybucji tychże środków.

Niepokoić może okoliczność, że bardzo często prawo w poszczególnych krajach przewiduje karalność wytwarzania i dystrybucji tychże substancji, a nie przewiduje karalności samego posiadania. Taka sytuacja ma miejsce także $w$ Polsce. Poważnym ostrzeżeniem i symbolem niewydolności prawodawcy w tej materii, a także sądów (mimo, że zjawisko to ciągle narasta), są bardzo liczne śmiertelne konsekwencje zażywania „dopalaczy” oraz sama wykładnia pojęcia „dystrybucja” w odniesieniu do tego rodzaju towarów. Wprawdzie Wojewódzki Sąd Administracyjny w Łodzi w wyroku z dnia 16 listopada 2017 r. - mając na uwadze treść art. 52a ustawy z dnia 29 lipca 2005 r. o przeciwdziałaniu narkomanii przewidującego karę pieniężną od 20 tys. do $1 \mathrm{mln}$ złotych w odniesieniu do osoby, która wytwarza lub wprowadza dopalacze lub nowe substancje psychoaktywne do obrotu w Polsce - oddalił skargę na decyzję Państwowego Wojewódzkiego Inspektora Sanitarnego wymierzającego karę pieniężną za dystrybucję dopalaczy ${ }^{52}$, co dawało nadzieję, że linia orzecznicza pozwoli ograniczyć ten niebezpieczny proceder. Tak się jednak nie stało. Symbolem niewydolności prawodawców i organów stosujących prawo (zwłaszcza sądów) stał się wyrok Wojewódzkiego Sądu Administracyjnego w Krakowie z dnia 29 maja 2018 r. w sprawie III SA/Kr 7/1853, którym w podobnej sytuacji i stanie faktycznym uchylił decyzję organu I i II instancji o nałożeniu kary pieniężnej. Wyrok spotkał się z generalną jego krytyką. Wydaje się, że jakość prawa w tej materii zależy także od organów stosujących prawo.

Po piąte, niewątpliwie dziś bardzo duże znaczenie mają zagadnienia związane z eliminowaniem dyktatu firm farmaceutycznych, które jako olbrzymie konglomeraty dysponują ogromnymi pieniędzmi, co niejednokrotnie ma wpływ na kształtowanie się prawa, pozwalającego na ustalanie cen leków i różnych środków medycznych na bardzo wysokim poziomie

52 Wyrok Wojewódzkiego Sądu Administracyjnego w Łodzi z dnia 16 listopada 2017 r., III SA/Łd 513/17, http:/ / www.orzeczenia-nsa.pl/ wyrok/iii-sa-ld-513-17 / 260d5f. html [dostęp: $27.08 .2018 \mathrm{r}$.].

53 Wyrok Wojewódzkiego Sądu Administracyjnego w Krakowie z dnia 29 maja 2018 r., III SA/Kr 7/18, http://www.orzeczenia-nsa.pl/wyrok/iii-sa-kr-7-18/nadzor_sanitarny_inspekcja_sanitarna/179a134.html [dostęp: 27.08.2018 r.]. 
- czasem kilkadziesiąt razy przewyższającym koszty ich wytwarzania. Wiąże się z tym niejednokrotnie problem naruszania zasad ochrony konkurencji i konsumentów. Problem ten ma szczególne znaczenie wtedy, gdy firmy farmaceutyczne kupują sobie przychylność lekarzy, stosując różne formy zachęty. Wydaje się, że niektóre z nich mogą być uznane - także $\mathrm{w}$ świetle prawa, które istnieje - $\mathrm{za}$ formę korupcji. Zagadnieniem niezwykle poważnym jest problem rejestracji leków, których wartość lecznicza może budzić wątpliwości, a także możliwość zakupu bez recepty leków o bardzo negatywnych skutkach ubocznych. Dla możliwości finansowania procedur medycznych ważne znaczenie ma to jakie leki znajdą się na liście leków refundowanych. Dość często wpisywane są na nią leki innowacyjne, podlegające ochronie patentowej, a przez to o wiele droższe od innych leków określanych mianem generycznych, których skuteczność może być taka sama jak leków innowacyjnych, ale cena ich jest niejednokrotnie dużo niższa. Wydaje się, że prawodawca, bez wykorzystania wiedzy medycznej $\mathrm{w}$ tym zakresie, nie jest $\mathrm{w}$ stanie tego przesądzić, a więc bez wiarygodnych informacji o ich skuteczności pochodzących od lekarzy i innych specjalistów. Dlatego też zasadne jest w tej materii zwrócenie uwagi na uczciwość środowiska medycznego i kształtowanie etosu lekarzy.

Po szóste, dla pełnej realizacji prawa do ochrony zdrowia dzieci, ważne znaczenie ma odpowiednie kształtowanie otoczenia, w którym żyć będzie i funkcjonować dziecko. Kluczowe znaczenie ma tu niewątpliwie ochrona zdrowia dziecka oraz ochrona macierzyństwa, a także ochrona rodziny (co ma odzwierciedlenie w Konstytucji RP), gdzie dziecko znajduje możliwość fizycznego, psychicznego i duchowego ładu w harmonii ze swoimi bliskimi. Znaczenie rodziny $\mathrm{w}$ tym kontekście jest dla zdrowia w pełnym wymiarze (fizycznym, psychicznym i duchowym) kluczowe. Należałoby ingerencję państwa w tym zakresie sprowadzić do niezbędnej konieczności. Państwo powinno niewątpliwie sprzyjać finansowemu wspomaganiu rodzin znajdujących się w trudnej sytuacji materialnej, zwłaszcza w przypadkach psychicznej lub fizycznej niepełnosprawności. Na zdrowie dziecka (realizację prawa do ochrony zdrowia) wpływ ma niewątpliwie cały szereg innych czynników, np. troska o ochronę środowiska, zapewnienie optymalnej obsługi medycznej we wszelkiego rodzaju jednostkach oświatowych i wychowawczych (żłobkach, przedszkolach i wszelkiego rodzaju szkołach), troska o rozwój kultury fizycznej itd.

Reasumując, stwierdzić należałoby, że konstytucyjnie gwarantowana szczególna ochrona zdrowia dzieci od ich poczęcia aż do uzyskania peł- 
noletniości, jest wartością, która winna być chroniona w sposób gwarantujący jej optymalne realizowanie. Ważne znaczenie $\mathrm{w}$ tym zakresie ma stworzenie i dążenie do ukształtowania spójnego, wydolnego i racjonalnego systemu prawa oraz ukształtowanie najwyższych standardów jego stosowania. Ważne znaczenie $\mathrm{w}$ tym zakresie ma rodzina, ochrona macierzyństwa, szkoła, a przede wszystkim państwo, na którym ciąży obowiązek ukształtowania optymalnego ładu prawnego, zarówno w zakresie tworzenia prawa, jak i jego stosowania.

Słowa kluczowe: ochrona praw dzieci, ochrona zdrowia

\section{Bibliografia}

Andrzejewski M., Konwencja o Prawach Dziecka - geneza i znaczenie, „Problemy Opiekuńczo-Wychowawcze" 2000, nr 5, s. 5-9.

Bański R., Granice prawnej ochrony wartości w spoteczeństwie demokratycznym - zakres ochrony wartości zdrowia człowieka, Kraków 2005.

Bińczycka J. (red.), Prawa dziecka - deklaracje i rzeczywistość. Materiały z Konferencji, Rembertów 19-21 czerwca 1992, Kraków 1993.

Czerwińska H., Prawo dziecka do godnego życia, „Remedium” 2003, nr 2, s. 1-3.

Dercz M., Konstytucyjne podstawy praw dziecka do ochrony zdrowia $i$ zadania władz publicznych w zakresie zapewnienia ich dostępności, [w:] M. Dercz, H. Izdebski, T. Rek, Dziecko - pacjent $i$ świadczeniobiorca. Poradnik prawny, Warszawa 2015, s. 25-53.

Dercz M., Konstytucyjne prawo dziecka do szczególnej opieki zdrowotnej, Warszawa 2016.

Dercz M., H. Izdebski, T. Rek, Dziecko - pacjent $i$ świadczeniobiorca. Poradnik prawny, Warszawa 2015.

Dercz M., H. Izdebski., T. Rek, Prawo publiczne ochrony zdrowia, Warszawa 2015.

Dercz M., T. Rek, Ustawa o działalności leczniczej. Komentarz, Warszawa 2014.

Gawrońska M., Prawo do ochrony zdrowia na gruncie Konstytucji Rzeczypospolitej Polskiej, „Przegląd Prawa Publicznego" 2014, nr 2, s. 7-17.

Gliszczyńska A., Międzynarodowy Pakt Praw Obywatelskich i Politycznych. Komentarz, Warszawa 2018.

Jan Paweł II, Encyklika "Evangelium vitae” o wartości i nienaruszalności życia ludzkiego, Kraków 1995.

Jan Paweł II, Encyklika "Veritatis splendor" o niektórych podstawowych problemach nauczania moralnego Kościoła, Kraków 1993. 
Jan Paweł II, Miłość i odpowiedzialność, Lublin 1960.

Jan Paweł II, Osoba i czyn, Kraków 1969.

Jan Paweł II, Przekroczyć próg nadziei, Lublin 1994.

Jan Paweł II, Przestanie do członków Papieskiej Akademii „Pro Vita” (19.II.2005 r.),

[w:] K. Gryz (oprac.), Godność: antologia tekstów, Kraków 2011, s. 130-132.

Jan Paweł II, W obronie życia i zdrowia każdej osoby ludzkiej, [w:] K. Gryz (oprac.), Godność: antologia tekstów, Kraków 2011, s. 75-85.

Jan Paweł II, Znak, któremu sprzeciwiać się będa, Paryż 1980.

Kędzia Z., Międzynarodowy Pakt Praw Gospodarczych, Socjalnych i Kulturalnych. Komentarz, Warszawa 2018.

Klafkowski A., Prawo międzynarodowe publiczne, Warszawa 1979.

Kondratiewa-Bryzik J., Początek prawnej ochrony życia ludzkiego w świetle standardów międzynarodowych, Warszawa-Kraków 2009.

Krąpiec M.A., Człowiek jako osoba, Lublin 2011.

Krąpiec M.A., Człowiek i prawo naturalne, Lublin 2009.

Krąpiec M.A., Ja - człowiek, Lublin 1974.

Krukowski J., Kościót i państwo: podstawy relacji prawnych, Lublin 1993.

Safjan M., Prawo i medycyna. Ochrona praw jednostki a dylematy współczesnej medycyny, Warszawa 1998.

Zdyb M., Aksjologiczne podstawy ochrony zdrowia, [w:] J. Pacian (red.), Prawna ochrona zdrowia pacjenta, Warszawa 2017, s. 11-33.

Zdyb M., Dylematy ładu prawnego w kontekście inflacji i niektórych innych niedoskonałości prawa administracyjnego, [w:] J. Jagielski, M. Wierzbowski (red.), Prawo administracyjne dziś i jutro, Warszawa 2018, s. 39-50.

Zdyb M., Systemowe obowiązki państwa w zakresie poszukiwania optymalnego modelu odpowiedzialności związanej z ochrona zdrowia. Zagadnienia podstawowe, [w:] M. Zdyb, A. Wołoszyn-Cichocka (red.), Odpowiedzialność w ochronie zdrowia, Warszawa 2018, s. 5-18.

Zdyb M., Wspótczesne aksjologiczne dylematy realizacji prawa do ochrony zdrowia przez władze publiczne i odpowiedzialności z tym zwiazanej, [w:] M. Zdyb, E. Kruk, A. Wołoszyn-Cichocka (red.), Odpowiedzialność w ochronie zdrowia, Warszawa 2018, s. 19-32.

Zoll A., Aborcja jest bezprawna, https://info.wiara.pl/doc/1008673.Aborcja-jest-bezprawna/2 [dostęp: 26.08.2018 r.].

Zoll A., Bezsporne jest, że dziecko poczęte jest człowiekiem. Teraz trzeba wyciagnać z tego odpowiednie konsekwencje, https://wpolityce.pl/polityka/120478-prof-andrzej-zoll [dostęp: 27.08.2018 r.].

Zoll A., Problemy stużby zdrowia w doktrynie w świetle doświadczeń RPO, „Prawo i Medycyna" 2000, nr 8, t. 2, s. 8-18. 


\section{PROTECTION OF CHILDREN'S RIGHTS IN POLISH AND INTERNATIONAL LAW IN THE CONTEXT OF PROTECTION OF THEIR HEALTH}

\section{Sum mary}

There is no doubt that the right to protect human life and health is the most crucial and fundamental human right. This right in relation to protection of life and health of children is particularly important. It should be stressed that a child is a human being from the moment of conception (and therefore also in the prenatal phase) until adulthood (as a rule, until reaching the age of eighteen). These rights are of primary nature, which means that the state does not provide them, but it is obliged to create conditions for their optimal implementation. A number of these rights have been confirmed in the Constitution of the Republic of Poland. The Constitution emphasizes the exceptional obligations of the state in the field of protection of life and health of everyone, which also refers to the protection of rights of a child as a patient. This problem has been broadly regulated in a number of acts of international law. The importance of the Convention for the Protection of Children's Rights deserves special mention. However, the basic role in this area belongs to the national legislator. Although currently in Poland this problem was regulated in many acts concerning health protection (and thus life), it should be considered that we are dealing with a highly unsatisfactory situation. Therefore, the legislator should be required to work hard to change this situation. This is undoubtedly in the interest of the state and citizens.

Key words: protection of children's rights, protection of their health

\section{ЗАЩИТА ПРАВ ДЕТЕЙ В ПОЛЬСКОМ И МЕЖДУНАРОДНОМ ПРАВЕ В КОНТЕКСТЕ ЗАЩИТЫ ИХ ЗДОРОВЬЯ}

\section{Резюме}

Нет сомнений в том, что наиболее важным и фундаментальным правом человека является право на защиту жизни и здоровья человека. Особое значение имеет ссылка этого права на жизнь и здоровье детей. Имея в виду ребенка, следует подчеркнуть, что это человек с момента зачатия (и, следовательно, также в предродовой фазе), пока он не достигнет совершеннолетия (как правило, это возраст 18 лет). Эти права носят первостепенный характер, что означает, что государство их не предоставляет, но оно обязано создавать условия для их оптимальной реализации. Ряд прав в этом вопросе подтвержден в Конституции Республики Польша, в которой обращается 
внимание на исключительные обязательства государства и всякую защиту права на жизнь, здоровье и обеспечение оптимальных условий для их защиты, включая права ребенка как пациента. Эта проблема решается в широком спектре международного права, где Конвенция о защите прав детей заслуживает особого подчеркивания. Однако основная задача в этой области лежит на национальном законодателе. Хотя в настоящее время в Польше этот вопрос регулируется многими актами, касающимися охраны здоровья (и, следовательно, жизни), следует предположить, что в настоящее время мы имеем дело с крайне неудовлетворительной ситуацией. Следовательно, законодатель должен приложить немало усилий, чтобы изменить эту ситуацию. Это, несомненно, находиться в интересах государства и граждан.

Ключевые слова: защита прав детей, охрана здоровья 
